\title{
C1 esterase inhibitor deficiency in X-linked hypogammaglobulinaemia: an anomaly fostering anaphylactoid reactions following intramuscular gammaglobulin administration
}

\author{
Shimon Pollack*, C. Cunningham-Rundlest, Robert A. Good and Noorbibi K. Day
}

Memorial Sloan-Kettering Cancer Center, 1275 York Avenue, New York, NY 10021, USA.

\begin{abstract}
Summary: A patient with apparent $\mathrm{X}$-linked agammaglobulinaemia was found to be inordinately susceptible to anaphylactoid reactions to intramuscular injections of gammaglobulin. The patient was found also to have low levels of $\mathrm{C} 1$ esterase inhibitor (C1 INH). The possibility that the C1 INH deficiency in this patient, whether genetic or acquired, fostered the susceptibility to the production of anaphylactoid reactions after gammaglobulin injections urges further studies of the association of C1 INH deficiency and anaphylactoid reactions to gammaglobulin injections. The possibility that C1 INH levels like C1q levels may be low in hypogammaglobulinaemic patients as a consequence of increased catabolism of this regulator of the complement system when IgG levels are low is considered.
\end{abstract}

\section{Introduction}

Congenital and acquired deficiencies of components of the complement system are associated with recurrent infections and collagen diseases (Day et al., 1977). In the sex-linked and common variable form of hypogammaglobulinaemia, low levels of $\mathrm{Clq}$ often occur which are attributable to an increased catabolism of Clq when serum IgG levels are low (Kohler \& Muller-Eberhard, 1972; Atkinson et al., 1978; Gewurz et al., 1968; Ballow et al., 1973). Inherited Clq deficiencies have been associated with both increased susceptibility to infection and mesenchymal disease (Berkel et al., 1981).

$\mathrm{Cl}$ esterase inhibitor ( $\mathrm{Cl} \mathrm{INH})$ is a serum protein which inhibits activated components of several systems including complement, plasmin, kallikrein and the clotting factors XII and XI (Frank et al., 1976). Deficiency of this inhibitor is usually genetically determined as an autosomal dominant (Frank et al., 1976) but may sometimes be acquired. Either deficiency leads to susceptibility to attacks of angioneurotic oedema (Day et al., 1976). In both the inherited disease and the acquired form of $\mathrm{Cl}$ INH deficiency, patients are liable to episodes of subcutan-

*Correspondence and present address: Shimon Pollack, M.D., Division of Clinical Immunology, Rambam Medical Center, Haifa 31096, Israel.

†Present address: All Children's Hospital, 801 6th Street

South St. Petersburg, FL 33701, USA.

Accepted: 30 April 1986 eous, laryngeal or mesenteric oedema which result from release of kinin-like peptides (C2-kinin) and the generation of $\mathrm{C} 3 \mathrm{a}$ anaphylatoxin due to triggering of complement activation (Frank et al., 1976). Trauma, infection, menstruation and physical stress have been implicated in triggering these attacks.

Patients with hypogammaglobulinaemia are maintained on gammaglobulin administration to prevent infections. Systemic reactions to gammaglobulin injections occur in about $10 \%$ of patients and mostly resemble anaphylactic reactions. However, reactions have been reported to be significantly less frequent in hypogammaglobulinaemic boys with affected male relatives (Soothill, 1971). The adverse effects following gammaglobulin administration are usually due to activation of complement by aggregated IgG but may also occasionally be attributable to the presence of antibodies to small amounts of contaminating serum proteins (Frank et al., 1976; Wahn et al., 1984; Day et al., 1984).

The aggregates of gammaglobulin, or the immune complexes formed, rarely cause symptoms after intramuscular injections of gammaglobulin unless they reach the circulation rapidly, or unless there is a functional failure of inhibitors of the complement cascade (Asherson \& Webster, 1980).

Here we describe a patient with X-linked hypogammaglobulinaemia who suffered from repeated anaphylactoid reactions following gammaglobulin injections given by the intramuscular route. The patient 
was found to have $\mathrm{Cl}$ esterase inhibitor deficiency. To the best of our knowledge, this association has not been described before.

\section{Case report}

This 27 year old white male was being followed in the Immunodeficiency Clinic of the Memorial Sloan-Kettering Cancer Center and had been diagnosed as having X-linked infantile (Bruton's) agammaglobulinaemia on the basis of very low levels of all circulating immunoglobulins, absence of B-cells in the blood and bone marrow, and presence of pre-B lymphocytes in the bone marrow. Over the last few years he had been given $20 \mathrm{ml}$ of $16.5 \%$ gammaglobulin by the intramuscular route once every 2 weeks. During this period the patient experienced recurrent episodes of severe anaphylactoid reactions which resolved completely within 2-3 hours, usually following administration of adrenaline. The anaphylactic reactions always developed a very short time after gammaglobulin administration and included shortness of breath, wheezing, tachycardia and hypotension. The patient had a brother who had also been diagnosed as having Bruton's agammaglobulinaemia, but who had died at 22 years of age with a fulminant bacterial infection. The latter patient had never experienced attacks following injections of gammaglobulin even though, like his sibling, he had been treated by intramuscular injections of gammaglobulin on a regular basis. There was no history of angioneurotic oedema or anaphylactic reactions among other family members.

Physical examination was unremarkable and routine laboratory findings were normal, except for the globulin level which was low $(0.9 \mathrm{~g} / \mathrm{dl})$. Immunoglobulin levels (while the patient was on gam- maglobulin treatment) were: IgG $240-271 \mathrm{mg} / \mathrm{dl}$ (normal range $700-1400$ ), IgA $0-26 \mathrm{mg} / \mathrm{dl}$ (normal range $100-400$ ), IgM 0-28 mg/dl (normal range 60-240) and $\mathrm{IgE} 9 \mathrm{IU} / \mathrm{ml}$ (normal range $0-100$ ). Salivary $\operatorname{IgA}$ was not detectable. E-rosette forming cells (T-cells) were $80 \%$ (normal) and latex ingesting cells (monocytes) were $11 \%$ (normal). Staining by immunofluorescence for cells with surface immunoglobulins (B-cells) was negative. In vitro lymphocyte responses to phytomitogens (PHA, Con-A, PWM) or antigens (Candida, E. coli, Staphylococcus aureus) were normal. Lymphocyte stimulation with several viral antigens (adenovirus, herpes virus and cytomegalovirus) resulted in normal positive responses. Mixed lymphocyte culture response to a pool of allogeneic cells was normal.

Analysis of subpopulations of T-cells by monoclonal antibodies revealed a normal percentage of total T-cells (OKT3 positive lymphocytes) - $61 \%$ (normal range 57\%-69\%), T-helper cells (OKT4 positive) cells $-48 \%$ (normal range; $39 \%-58 \%$ ) and T-suppressor cells $-28 \%$ (normal range; $17 \%-30 \%$ ). Neither isohaemagglutinins nor autoantibodies (antinuclear antibody or rheumatoid factor) were found in the serum and no anti-IgA antibodies could be detected.

\section{Complement studies}

Total haemolytic activity of complement $\left(\mathrm{CH}_{50}\right)$ and? functional activity of $\mathrm{C} 2$ and $\mathrm{C} 4$ were determined by methods previously described (Day et al., 1973). Clq and $\mathrm{C} 3$ levels were measured by immunodiffusion using monospecific antisera prepared against the purified components (Day et al., 1973). Immune complexes were quantified by the Raji cell assay (Theofilopoulos et al., 1976). C1 esterase inhibitor

Table I Complement components study of patient and father

\begin{tabular}{|c|c|c|c|c|c|c|c|}
\hline & $\begin{array}{l}\text { C1 INH } \\
(U / \mathrm{ml})\end{array}$ & $\begin{array}{c}\mathrm{CH}_{50} \\
(\mathrm{U} / \mathrm{ml})\end{array}$ & $\begin{array}{c}C 1 q \\
(\mu g \text { nitrogen } / \mathrm{ml})\end{array}$ & $\begin{array}{c}C 3 \\
(m g / d l)\end{array}$ & $\begin{array}{c}C 2 \\
\left(C H_{50} \mathrm{U} / \mathrm{ml}_{\text {serum }}\right)\end{array}$ & $\begin{array}{c}C 4 \\
\left(\mathrm{CH}_{50} \mathrm{U} / \mathrm{ml}_{\text {serum }}\right)\end{array}$ & $\begin{array}{c}\text { Immune } \\
\text { complexes } \\
\left(\mu \mathrm{g} / \mathrm{ml}_{\text {serum }}\right) \S\end{array}$ \\
\hline \multicolumn{8}{|l|}{ Patient } \\
\hline Test No. $1^{*}$ & $5.7(13.6) \dagger$ & 70 & 21 & 84 & ND $\ddagger$ & ND & $<16$ \\
\hline 2 & $3.5(9.5)$ & 113 & 10 & 122 & 1499 & 257,855 & $<16$ \\
\hline 3 & $1.0(6.0)$ & 146 & 17 & 104 & 1318 & 428,743 & $<16$ \\
\hline Father & $6.5(6.0)$ & 116 & 31 & 119 & ND & ND & $<16$ \\
\hline Normal range & $6.0-13.6$ & $50-110$ & $17-23$ & $80-180$ & $850-1850$ & $144,500-347,500$ & $<16$ \\
\hline
\end{tabular}

*Test No. 1: 14 days after gammaglobulin injection. Test No. 2: 6 days after gammaglobulin injection. Test No. 3: 14 days after gammaglobulin injection. On this day, patient was given gammaglobulin injection i.m. and developed a severe anaphylactic reaction.

$\dagger N u m b e r s$ in parentheses indicate the level of normal control for that day test. $\ddagger N D=$ not done.

$\S \mu$ equivalent human aggregated gammaglobulin $/ \mathrm{ml}$. 
activity was measured functionally according to methods previously described (Day et al., 1976). The results of these studies are summarized in Table I. Of all the family members, only the father of the patient was available for study and his $\mathrm{C}^{\prime}$ system was normal in every respect. The patient's total haemolytic complement $\left(\mathrm{CH}_{50}\right), \mathrm{C} 4$ and $\mathrm{C} 2$ levels (measured functionally), C3 (measured immunochemically) and circulating immune complexes were within normal limits (Table I). C1 INH and Clq, however, were decreased in the patient's sera.

\section{Discussion}

This patient with apparent $\mathrm{X}$-linked agammaglobulinaemia had a much greater frequency of severe clinically significant reactions to intramuscular gammaglobulin than is usually seen in X-linked recessive agammaglobulinaemia or hypogammaglobulinaemic patients (Soothill, 1971). In fact, the reactions were so severe as to ultimately prevent the use of intramuscular gammaglobulin preparations in this patient's treatment. These reactions were associated with consistently low levels of C1 INH. As is frequently seen in hypogammaglobulinaemic patients, levels of $\mathrm{Clq}$ were also sometimes low. The C1 INH deficiency could not be shown to be of an hereditary form; however, conclusive family studies could not be carried out. Nonetheless, it seems attractive to postulate that, as in other forms of acquired $\mathrm{C} 1 \mathrm{INH}$ deficiencies, increased consumption or catabolism of $\mathrm{C} 1 \mathrm{INH}$ was responsible for the low levels in this patient. On the basis of the findings in this patient, studies of $\mathrm{C} 1 \mathrm{INH}$ levels in agamma- and hypogammaglobulinaemic patients seem in order, especially to determine whether a propensity to anaphylactoid reactions to gammaglobulin relate in a more general way to low levels of $\mathrm{C} 1 \mathrm{INH}$. The possibility exists that $\mathrm{C} 1 \mathrm{INH}$ levels, like C1q levels, may be lower than normal in hypogammaglobulinaemic patients due to increased catabolism of C1 INH (Kohler \& MullerEberhard, 1972; Atkinson et al., 1978). Further studies of $\mathrm{Cl}$ INH in hypogammaglobulinaemic patients seem indicated for this reason alone. Alternatively, $\mathrm{Cl}$ production may have been depressed in our patient, leading to a failure to clear aggregates of gammaglobulin in the preparation.

Although there are clear deficiencies in our study of this patient (e.g. metabolism of C1 INH was not evaluated), clinical circumstances precluded further analysis. Nonetheless, the association, for the first time, of low levels of $\mathrm{Cl}$ INH and susceptibility to anaphylactoid reactions to gammaglobulin are provocative, and should generate definitive additional studies of these relationships.

\section{Acknowledgements}

This work was supported by grants awarded by the March of Dimes National Birth Defects Foundation 1-789, and from the National Institutes of Health, AG-03592.

\section{References}

ASHERSON, G.L. \& WEBSTER, A.D.B. (1980). In Diagnosis and Treatment of Immunodeficiency Diseases. p. 336. Blackwell Scientific Publications: London.

ATKINSON, J.P., FISHER, R.I., REINHARDT, R. \& FRANK, M.M. (1978). Reduced concentrations of the first component of complement in hypogammaglobulinemia: correction by infusion of gammaglobulin. Clinical Immunology and Immunopathology, 9, 350.

BALLOW, M., DAY, N.K., BIGGAR, W.D., PARK, B.H., YOUNT, W.J. \& GOOD, R.A. (1973). Reconstitution of Clq after bone marrow transplantation in patients with severe combined immunodeficiency. Clinical Immunology and Immunopathology, 2, 28.

BERKEL, A.I., LOOS, M., SANAL, O., EZSOY, F. \& YEGIN, O. (1981). Selective complete Clq deficiency. Report of two new cases. Immunology Letters, 2, 263.

DAY, N.K., GEIGER, H., MACLEAN, R., RESNICK, J., MICHAEL, A. \& GOOD, R.A. (1973). The association of respiratory infection, recurrent hematuria and focal glomerulonephritis with activation of the complement system in the cold. Journal of Clinical Investigation, 52, 1998.

DAY, N.K., WINFIELD, J.B., GEE, T., WINCHESTER, R., TESHIMA, H. \& KUNKEL, H.G. (1976). Evidence for immune complexes involving anti-lymphocyte antibodies associated with hypocomplementemia in chronic lymphocytic leukemia. Clinical and Experimental Immunology, 26, 189.

DAY, N.K., MOCADA, B. \& GOOD, R.A. (1977). Inherited deficiencies of the complement system. In Comprehensive Immunology No. 2, Good, R.A. \& Day, S.B. (eds). Biological Amplification System in Immunology, pp. 229-245. Plenum Medical Book Company: New York and London.

DAY, N.K., GOOD, R.A. \& WAHN, V. (1984). Adverse reactions in selected patients following intravenous infusions of gammaglobulin. American Journal of Medicine, $76,25$.

FRANK, M.M., GELFAND, J.A. \& ATKINSON, J.P. (1976). Hereditary angioedema: the clinical syndrome and its management. Annals of Internal Medicine, 84, 580.

GEWURZ, H., PICKERING, R.J., CHRISTIAN, C.L., SNYDERMAN, R., MERGENHAGEN, S.E. \& GOOD, R.A. (1968). Decreased $\mathrm{Clq}$ protein concentration and agglutinating activity in agammaglobulinemia syndromes: an inborn error reflected in the complement system. Clinical and Experimental Immunology, 3, 437.

KOHLER, P.F. \& MULLER-EBERHARD, H.J. (1972). 
Metabolism of human $\mathrm{Cl}$. Studies in hypogammaglobulinemia, myeloma and systemic lupus erythematosus. Journal of Clinical Investigation, 51, 868.

SOOTHILL, J.F. (1971). Reactions to immunoglobulins. In Hypogammaglobulinaemia in the United Kingdom. MRC Special Report Series, 310, 106.

THEOFILOPOULOS, A.N., WILSON, C.B. \& DIXON, F.J. (1976). The Raji cell radioimmune assay for detecting of immune complexes in human sera. Journal of Clinical
Investigation, 57, 169.

WAHN, V., GOOD, R.A., GUPTA, S., PAHWA, S. \& DAY, N.K. (1984). Evidence of persistent IgA/IgG circulating immune complexes associated with activation of the complement system in serum of a patient with common variable immunodeficiency: anaphylactic reactions to intravenous gammaglobulin. Acta Pathologica et Microbiologica Scandinavica Sec C (Suppl. 284), 92, 49. 